\title{
Life Ventures
}

Priscilla Redondo Arias

$\mathrm{O}$

$h$ vast, majestic Waters

Whose ferocity sinks creatures into treacherous swirls And lugs them through dangerous

In foggy nights!

[tempests

Deep Waters that drags creatures, Subjects to your whim, leading them To taste heavy rains, thunders, and [gales

Trapping them to perish by Your infinite

Oh Ocean!

[power

But, when it is Your will,
You choose to bestow creatures with

Dazzled and calmed sunsets

Granting tranquility

Like a mother who pleases her children After their suffering,

As a mast that affords serenity and

When tempests come and

Buoys warn captains,

You marvelous restless Streams!

Cloudy horizons, squally Seas,

And startled whirlwinds,

If You encounter quietude,

Creatures may lay in Your lap. 


\section{Wings inside Her}

Priscilla Redondo Arias

$\mathrm{F}$ or many years she was not free. It was a cage where she had a tough time because she was the prisoner of her past. People around her didn't want to give her a chance. They always remembered her mistakes, or maybe it was just that she didn't belong there with them. After many years of waiting, it came time to leave that cage. She finally felt free for the first time in her life. She was able to explore another world: a very different one from the one that she was attached to. Everything was beautiful outside that cage. It was so wonderful that she forgot the past, and she thought it would never ever come back. She learned many new things, and she was so happy. But some years passed until she realized that she was, again, inside a cage but now prisoner of her own decisions. This time, she tried very hard to make a good choice, but she was afraid to leave that cage: it was her security, and, somehow, she had been happy there. So it was very difficult because, at the same time, she didn't want to leave that cage. She had built her life in this cage and then leaving it was not easy at all, but she had to because it was hurting her to feel like a prisoner again. Finally, she found a way to escape, but then she felt lost. This was the worst time of her life. Nothing was safe. Once again, she had to start over, to explore the unknown environment, and to go as far as possible from that cage. Some time passed, and she realized that she would always be trapped in a cage, because of her nature. She put all her effort into continuing but, this time, within the bounds of her own reality. She finally understood her reality and was able to deal with it. The most important part was that she was completely sure about one thing: at the end, she was going to be free and to fly happily forever. Her pain and questions would be gone someday at the end of her journey. 